\title{
VOLUME ESTIMATE FOR THREE TIMBER SPECIES WITH COMMERCIAL INTEREST FROM THE DIAMETER OF THE STUMP
}

\author{
Quelyson Souza de Lima ${ }^{*}$, Thiago Augusto da Cunha², Marco Antonio Amaro ${ }^{3}$, Evandro Orfanó Figueiredo ${ }^{4}$ \\ Paulo Roberto Feitosa Parente ${ }^{5}$ \\ 1*Instituto de Meio Ambiente do Acre, Divisão de Manejo Florestal, Rio Branco, Acre - quelyson.lima@ gmail.com \\ 2Universidade Federal do Acre, Centro de Ciências Biológicas e da Natureza, Rio Branco, Acre - etsfor@yahoo.com \\ ${ }^{3}$ Universidade Federal do Acre, Centro de Ciências Biológicas e da Natureza, Rio Branco, Acre - marcoantonioamaro@gmail.com \\ ${ }^{4}$ Empresa Brasiliera de Pesquisa Agropecuária, Rio Branco, Acre - evandro.figueiredo@embrapa.br \\ ${ }^{5}$ Complexo Industrial Florestal Xapuri S.A., Xapuri, Acre - paulorfparente@ hotmail.com \\ Received for publication: 16/04/2020 - Accepted for publications: 18/09/2020
}

\begin{abstract}
Resumo
Estimativa do volume para três espécies de interesse comercial madeireiras a partir do diâmetro do toco. O volume comercial de árvores pode ser calculado de forma direta e indireta. Entretanto em áreas de desmatamento ilegal, muitas vezes o fuste não está disponível para medições dendrometricas e, consequentemente, cálculo do volume comercial, e a utilização do método direto. Por outro lado, o uso do método indireto é impossível devido a não existência de equações com variáveis de possível medição. Para viabilizar a estimativa de volume nestes casos, o objetivo desse trabalho foi estimar o volume comercial de madeira de árvores individuais através de equações de regressão, utilizando medições realizadas no toco para três espécies de interesse comercial, em áreas de manejo florestal madeireiro, sendo elas: Dipteryx odorata (Aubl.) Willd., Apuleia leiocarpa (Vogel) J.F.Macbr. e Amburana acreana (Ducke) A.C.Sm.. Os dados foram coletados em duas áreas de manejo, localizadas nos municípios de Sena Madureira e Rio Branco, com amostra de 250 tocos. Foram realizados testes estatísticos para análise de regressão e escolha das melhores equações que estimassem o volume das espécies selecionadas para o estudo, à partir do diâmetro do toco. Testes de exatidão, precisão, pressupostos, validação e modelo identidade foram aplicados para escolha. Foram testados modelos que atenderam os objetivos da pesquisa para ambas as espécies com $\mathrm{R}^{2}$ ajus $=87,7 \%$ para Dipteryx odorata (Aubl.) Willd., $\mathrm{R}_{\text {ajus }}=81,8 \%$ para Apuleia leiocarpa (Vogel) J.F.Macbr. e $\mathrm{R}^{2}$ ajus $=70,5 \%$ para Amburana acreana (Ducke) A.C.Sm., assim como atenderam todos os pressupostos da regressão tendo como resultado a validação das equações ajustadas pelos modelos selecionados.

Palavras-chave: Floresta Amazônica; alometria; fiscalização ambiental.
\end{abstract}

Abstract
The commercial volume of trees can be calculated directly and indirectly. However, in areas of illegal deforestation, the stem is often not available for dendrometric measurements and, consequently, calculation of the commercial volume and the use of the direct method. On the other hand, the use of the indirect method is impossible due to the lack of equations with possible measurement variables. In order to make the volume estimate feasible in these cases, the objective of this work was to estimate the commercial volume of wood from individual trees using regression equations, using measurements made on the stump for three species of commercial interest, in areas of timber forest management, namely: Dipteryx odorata (Aubl.) Willd., Apuleia leiocarpa (Vogel) JFMacbr. and Amburana acreana (Ducke) A.C.Sm. Data were collected in two management areas, located in the municipalities of Sena Madureira and Rio Branco, with a sample of 250 stumps. Statistical tests were carried out to analyze regression and choose the best equations that would estimate the volume of the species selected for the study, based on the diameter of the stump. Tests of accuracy, precision, assumptions, validation and identity model were applied for choice. Models that met the research objectives for both species were tested with $\mathrm{R}^{2} \mathrm{adj}=87.7 \%$ for Dipteryx odorata (Aubl.) Willd., $\mathrm{R}^{2} \mathrm{adj}=81.8 \%$ for Apuleia leiocarpa (Vogel) J.F.Macbr. and $\mathrm{R}^{2} \mathrm{adj}=70.5 \%$ for Amburana acreana (Ducke) A.C.Sm., as well as meeting all the assumptions of the regression resulting in the validation of the equations adjusted by the selected models. Keywords: Amazon rainforest; allometry; environmental inspection.

\section{INTRODUCTION}

Illegal logging still occurs in the Amazon rainforest and has been developing in extensive areas of vegetation cover, causing immeasurable losses of genetic resources, where rare species have been decimated and several habitats have been modified by anthropic actions, affecting the resistance and resilience of ecosystems (SILVA et al., 2015). Combined with occupation and deforestation, this activity results in a real threat to the protection of biodiversity in the Legal Amazon (LEMOS; SILVA, 2011), provided deforestation is a catalyst for forest fragmentation resulting in changes in carbon stocks (BARROS; FEARNSIDE, 2016).

One of the attempts to reduce illegal logging in the Amazon was Provisional Measure 1511/96, which increased the Legal Reserve from 50\% to 80\% (ALMEIDA et al., 2013). However, other alternatives have been 
developed over time in order to adjust policy and resource allocation in the face of current forest destruction (GODAR et al., 2012).

According to Amin et al. (2019), the creation of conservation units can also be a strategy for reducing deforestation rates in the Brazilian Amazon, since extensive areas are created aimed at the protection and/or sustainable use of resources.

In the case of inspection in areas of illegal logging, obtaining the commercial volume in an accurate manner is of relevant importance for the better legal framing of the Notices of Infractions according to Federal Decree No. 6514/2008, which is the administrative legal basis used for legal framing of the infraction.

Therefore, calculating the volume of timber harvested in areas of illegal deforestation during environmental inspection actions is difficult given the situation that in many cases only the stump remains as part of the tree, which makes it impossible to adopt classic methods for calculating the volume from diameter measurements along the stem.

Some authors estimate the commercial volume of trees based on measures of the diameter of the stump as an input variable in a regression equation (GIMENEZ et al., 2015); (LEITE; REZENDE, 2010). Other authors used stump measurements, namely height and diameter, to obtain the diameter at breast height estimate in order to estimate the volume of a population (PONDE; FROESE, 2014); (WESTFAL, 2010).

However, the accuracy of estimates for volume from regression equations deserves to be evaluated in view of the great diversity of forms of timber species in the Amazon. In this way, this research evaluated the performance of the estimation of regression equations to calculate the commercial volume of trees harvested illegally, using measures of the remaining stump in the forest. The species evaluated correspond the main trees currently exploited in the state of Acre: Dipteryx odorata (cumaru-ferro), Apuleia leiocarpa (garapeira) and Amburana acreana (cerejeira) (SILVA et al., 2015).

\section{MATERIAL AND METHODS}

The trees used for this study were sampled within two Annual Production Units (APU) in a forest management regime located in the municipalities of Rio Branco and Bujarí in the state of Acre (Eldorado Farm UTM X 643083,400 and Y 8886079,195 and Antimary State Forest (X 606238,686 X and Y 8968718,409 Y) as shown in Figure 1.

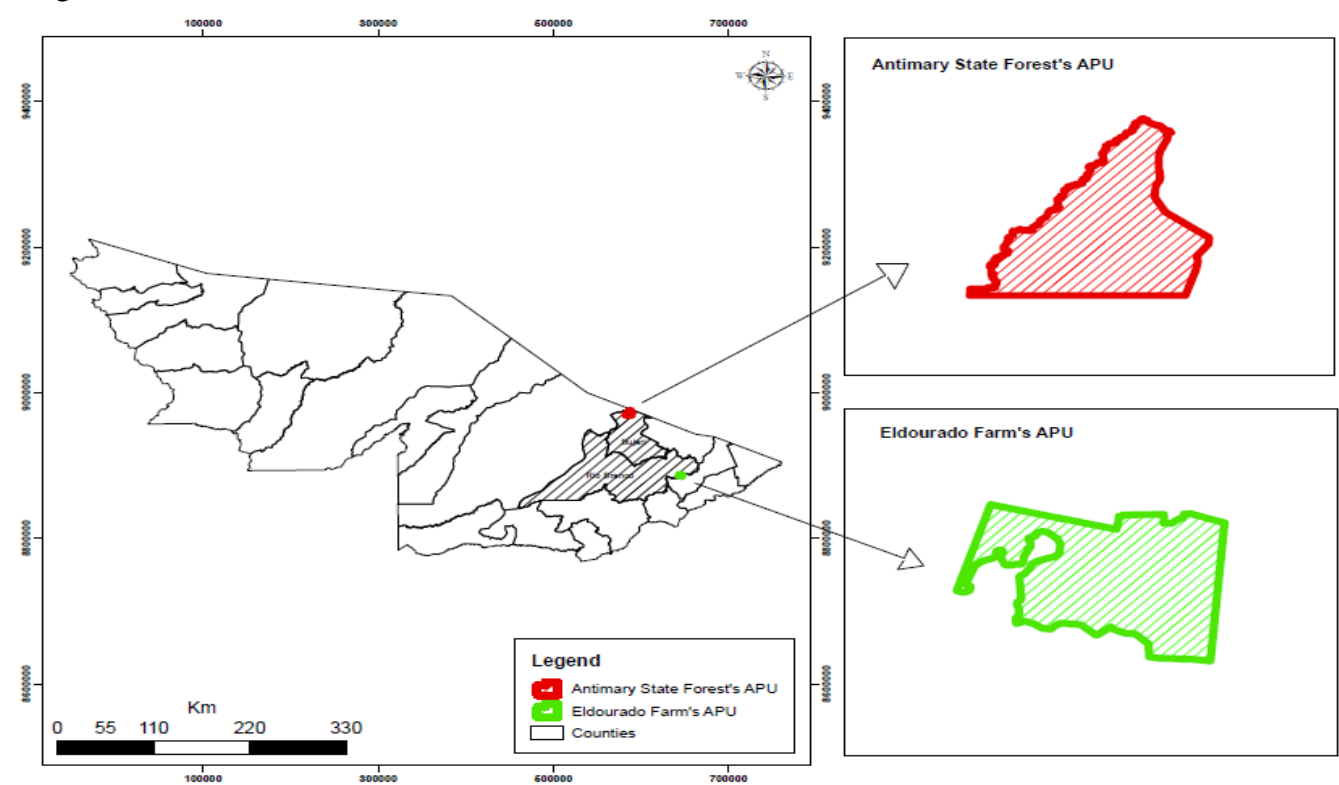

Figure 1. Map of the location of study areas in the State of Acre.

Figura 1. Mapa de localização das áreas de estudo no Estado do Acre.

This state has an average rainfall of $1944 \mathrm{~mm}$ per year (range 1566-2425 mm per year) with a rainy period occurring between October to April and the dry season between June to August, with the months of May and September comprising the dry season, when rainfall reaches levels below $50 \mathrm{~mm}$ (DUARTE, 2006).

The vegetation of the Eldourado Farm is predominantly classified as Open Forest with Palm Trees, while the Antimary State Forest has vegetation of the type Open Forest with Palm and Open Forest with Bamboo. The predominant type of landscape in the study areas is the gently undulating plain, and the dominant soils that occur 
in the areas covered by the municipalities, where the areas of the properties are located, belong to the Argisols and Latosols Classes.

\section{Species evaluated and strategy for data collection and modeling}

The selected individuals are in a group with the highest rates of exploitation in the state of Acre, being the species Dipteryx odorata (Aubl.) Willd. (cumaru-ferro), Apuleia leiocarpa (Vogel) J.F.Macbr. (garapeira) and Amburana acreana (Ducke) A.C.Sm. (cherry tree). These species are also the main forest essences licensed in the state of Acre (SILVA et al., 2015).

To measure the botanical recognition, exsiccates collected in the field were used, which were compared with exsiccates deposited in the herbarium of the Federal University of Acre (UFAC).

Of the total number of trees legally felled within the APU by forestry activities, 250 individuals were randomly selected, distributed among the three species and stratified into six classes of DBH, with the amplitude of class $10 \mathrm{~cm}$, the lowest DBH $50 \mathrm{~cm}$ and the largest greater than $100 \mathrm{~cm}$. The frequency of the lowest class was 5 and greater than 26 individuals.

To locate the felled trees, GPS navigation Garmim 76 CSX with UTM coordinates, DATUM SIRGAS 2000 was used with the aid of the exploration map.

On each localized stem, the dimensions of diameter and length were measured for applying Smalian's formula for each section. The volme of each section were summed to reconstruct the stem and obtain the total commercial volume for each individual.

The average diameter of the respectively stump also were calculated. The measures was obtained from two directions with $90^{\circ}$ angles for shapes tending to cylindrical. In the case of presence of buttress, the average diameter was calculated from several measurements of diameters considering all extremities (buttress), and the geometric mean was calculated according to the methodology proposed by Gimenez et al. (2015).

To mathematically describe the observed data of commercial volume of logs we used the average diameter of the stump as a predictor by fitting five regression models (Table 1).

The decision to use the regression models was based on the behavior of the data observed in dispersion diagram graphs considering the commercial volume as a function of the average diameter of the stump based on the biological behavior (VANCLAY; SKOVSGAARD, 1997).

Table 1. Models tested for the adjustment of the volumetric equations as a function of the diameter of the stump. Tabela 1. Modelos testados para o ajuste de regressão para equação volumétrica em função do diâmetro do toco.

\begin{tabular}{ccc}
\hline Number & Model & Authors \\
\hline $\mathbf{1}$ & $\operatorname{Ln} V_{c}=\beta_{0}+\beta_{1} \operatorname{Ln} D_{t}+\varepsilon$ & Husch \\
$\mathbf{3}$ & $\operatorname{Ln} V_{c}=\beta_{0}+\beta_{1} \operatorname{Ln} D_{t}+\beta_{2} D_{t}^{-1}$ & Brenac \\
$\mathbf{4}$ & $V_{c}=\beta_{0}+\beta_{1} D_{t}^{2}+\varepsilon$ & Kopezky-Gehrhrdt \\
$\mathbf{5}$ & $V_{c}=\beta_{0}+\beta_{1} D_{t}+\varepsilon$ & Berkhout \\
\hline Where: $\mathrm{V}_{\mathrm{c}}=$ commercial volume; $\mathrm{D}_{\mathrm{t}}=$ stump diameter $\beta=$ regression coefficient; $\varepsilon=$ residue. & Hohenald \& Krenn
\end{tabular}

\section{Initial analysis}

In order to indicate the analyses, it is necessary to know the behavior between the variables, so it was necessary to build a dispersion graph and an analysis of Pearson's Correlation (r) (CUNHA et al., 2016). In addition, the behavior of the data studied was observed, including their minimum, maximum and average values, since they can assist in making technical decisions due to the similarities of the measured and morphological variables.

\section{Selection criteria for the best equation}

In the statistical analysis performed on the SAS System V8, a probability of $\alpha=0.05$ was considered, as recommended by Cunha et al. (2016).

To choose the best regression equation for volume estimation, accuracy statistics were used according to Figueiredo et al. (2014); Amaro et al. (2013): Value F, Adjusted Coefficient of Determination (R²adj\%), Standard Error of the Estimate $\left(\right.$ Syx $\left.\mathrm{m}^{3}\right)$ and Coefficient of Variation $(\mathrm{CV} \%)$.

FI was used to compare regression equations with different units for the dependent variable, as reported by Viana et al. (2013).

In order to control the effects of collinearity in multiple regression models, as proposed by Ribeiro et al. (2014), the Variance Inflation Factor (VIF) was calculated. Thus, only the equations remained in which all the independent variables showed VIF values less than 5 (CUNHA et al., 2016). 
Equations with VIF greater than 5 and non-significant regression coefficients in at least one regression variable were excluded.

The Pondered Value (PV) was applied to select the best one according to the scores of each equation (SOUSA et al., 2013).

For the best selected regression equation, assumptions of regression tests were carried out according to Ribeiro et al. (2014); Schröder et al. (2013), for normality (Shapiro-Wilk test), homogeneity of variance (White test) and independence of residues (Durbin-Watson test).

Finally, the graphic distribution of the residues was verified to observe the behavior of the data for the selected equation, since according to Amaro et al. (2013) residues are important elements to visualize the performance of the regression equation.

\section{Equation validation}

For the validation of the best adjusted equation, the Chi-square test was used according to the methodology proposed by Ribeiro et al. (2014), by collecting a new sample of 15 pairs of data per species (volume and diameter of the stump). As recommended by Leal et al. (2015), the collection was carried out in an area of forest different from the main sample.

This methodology aims to evaluate the effectiveness of the estimates in the face of different situations in which the trees are.

\section{Model identity}

To assess the adequacy of a single regression equation for the three species, each equation passed the identity test, determined by the covariance analysis which assessed the influence of a common intercept (species) and the interaction (species $\times$ LnDt) for the purpose of an angular coefficient, with a probability test on different values of diameter of the stump.

After the selection and verification of the tests for choosing the model, the possibility of grouping the species to fit a single equation was verified through the test (CYSNEIROS et al., 2017).

For all statistical analyses, the SAS System version SAS University was used, considering the PROC REG procedures for regression analysis, PROC CORR for correlation analysis, PROC MODEL for the analysis of regression assumptions and PROC GLIMMIX for the analysis of covariance.

All statistical analyses were performed using the SAS System V8 with an alpha significance level of 0.05 (CUNHA et al., 2016).

\section{RESULTS}

Pearson's Linear Correlation results showed a positive association between the variables for the three species, with Dipteryx odorata $\mathrm{r}=0.93$, Apuleia leiocarpa $\mathrm{r}=0.90$ and Amburana acreana $\mathrm{r}=0.83$.

It is important to highlight that Amburana acreana was the species that showed the lowest correlation between the variables, even with a strong association. The lowest correlation value occurred for Amburana acreana since the dispersion of the data pairs showed a slight slope in the dispersion, different from the other species that present a more accentuated linear trend (Figure 2).

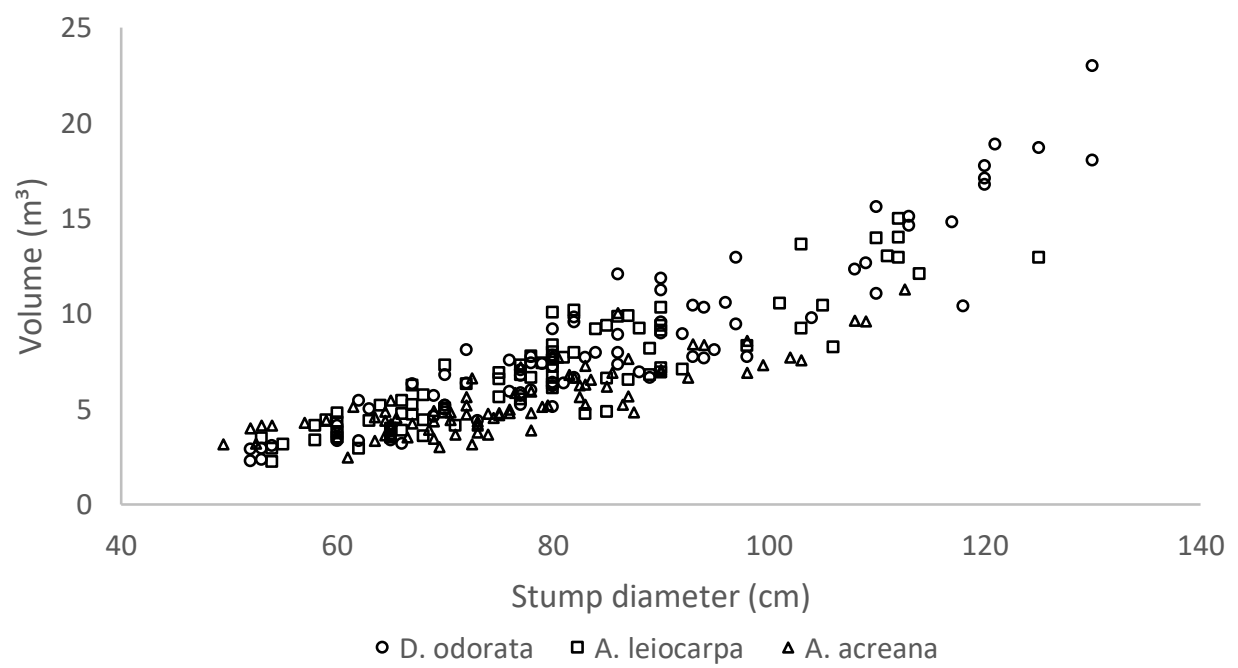

Figure 2. Pearson's correlation graph for the volume and diameter of the stump.

Figura 2. Gráfico de correlação de Pearson para volume e diâmetro do toco. 
For the average of the diameters, we can observe that the species $D$. odorata obtained the highest result for this statistical variable, being an average of $84.7 \mathrm{~cm}$, followed by A. leiocarpa with $79.38 \mathrm{~cm}$ and A. acreana with $76.33 \mathrm{~cm}$. This is due to the fact that the first two species have a greater number of individuals larger than the third (Table 2).

Regarding the average value of the cubed volume and the estimated average volume obtained through the equation, a small variation was observed between them, with A. acreana $0.00001 \mathrm{~m}^{3}$, A. leiocarpa $0.09438 \mathrm{~m}^{3}$ and D. odorata $0.10687 \mathrm{~m}^{3}$ (Table 2).

It can also be observed that the smallest variation between the observed and estimated volumes adjusted through the selected equation was for the species A. acreana with variation of $0.00001 \mathrm{~m}^{3}$, A. leiocarpa with $0.09438 \mathrm{~m}^{3}$ and D. odorata with $0.10687 \mathrm{~m}^{3}$ (Table 2).

Table 2. Observed of values of attributes of the three species evaluated.

Tabela 2. Valores observados de atributos das três espécies avaliadas

\begin{tabular}{lcccc}
\hline \multicolumn{1}{c}{ Species } & Variables & $\begin{array}{c}\text { Stump diameter } \\
(\mathbf{c m})\end{array}$ & $\begin{array}{c}\text { Cubing volume } \\
\left(\mathbf{m}^{\mathbf{3}}\right)\end{array}$ & $\begin{array}{c}\text { Volume of equations } \\
\left(\mathbf{m}^{\mathbf{3}}\right)\end{array}$ \\
\hline \multirow{2}{*}{$\begin{array}{l}\text { Dipteryx odorata } \\
(\mathrm{n}=85)\end{array}$} & Minimum & 52 & 2,30392 & 2,77664 \\
& Maximum & 130 & 23,01091 & 19,3938 \\
& Medium & 84,7 & 8,402550 & 8,29568 \\
\hline \multirow{2}{*}{$\begin{array}{l}\text { Apuleia leiocarpa } \\
(\mathrm{n}=82)\end{array}$} & Minimum & 53 & 2,25211 & 3,10085 \\
& Maximum & 125 & 15,01581 & 15,91175 \\
\hline \multirow{2}{*}{$\begin{array}{l}\text { Amburana acreana } \\
(\mathrm{n}=83)\end{array}$} & Medium & 79,38 & 7,036870 & 6,94249 \\
\hline
\end{tabular}

The equations generated by the processing of the regression models tested are shown in Table 3, where the species, model and the resulting equation of the adjustment are presented.

Table 3. Equations adjusted by the models for the evaluated species.

Tabela 3. Equações ajustadas pelos modelos para as espécies avaliadas

\begin{tabular}{|c|c|c|}
\hline Species & Model & Equation \\
\hline \multirow{5}{*}{ Dipteryx odorata } & 1 & $\mathrm{LnV}=-7,36045+2,12128 \times \mathrm{LnDt}$ \\
\hline & 2 & $\mathrm{LnV}=-9,03143+2,61062 \times \mathrm{LnDt}+0,00577 \times 1 / \mathrm{Dt}$ \\
\hline & 3 & $\mathrm{~V}=-0,37752+0,00116 \times \mathrm{Dt}^{2}$ \\
\hline & 4 & $\mathrm{~V}=-0,2702+0,20864 \times \mathrm{Dt}$ \\
\hline & 5 & $V=1,03921-0,03266 \times D t+0,00134 \times D^{2}$ \\
\hline \multirow{5}{*}{ Apuleia leiocarpa } & 1 & $\mathrm{LnV}=-6,43566+1,90599 \times \mathrm{LnDt}$ \\
\hline & 2 & $\mathrm{LnV}=-10,71269+3,17590 \times \mathrm{LnDt}-0,01577 \times 1 / \mathrm{Dt}$ \\
\hline & 3 & $\mathrm{~V}=0,73398+0,00095936 \times \mathrm{Dt}^{2}$ \\
\hline & 4 & $V=-5,96631+0,16381 \times \mathrm{Dt}$ \\
\hline & 5 & $\mathrm{~V}=-5,37752+0,14925 \times \mathrm{Dt}+0,00008635 \times \mathrm{Dt}^{2}$ \\
\hline \multirow{5}{*}{ Amburana acreana } & 1 & $\mathrm{LnV}=-4,54407+1,43334 \mathrm{x} \mathrm{LnDt}$ \\
\hline & 2 & $\mathrm{LnV}=3,91565-1,11588 \times \mathrm{LnDt}+0,03344 \times 1 / \mathrm{Dt}$ \\
\hline & 3 & $\mathrm{~V}=1,25518+0,00070003 \times \mathrm{Dt}^{2}$ \\
\hline & 4 & $\mathrm{~V}=-2,96777+0,11041 \times \mathrm{Dt}$ \\
\hline & 5 & $\mathrm{~V}=4,13679-0,07375 \times \mathrm{Dt}+0,00116 \times \mathrm{Dt}^{2}$ \\
\hline
\end{tabular}

Where: $\mathrm{LnV}=$ Natural volume logarithm; V = volume $\left(\mathrm{m}^{3}\right) ; \mathrm{LnDt}=$ Natural logarithm of the stump diameter; Dt $=$ Stump diameter $(\mathrm{cm})$.

For the species Dipteryx odorata and Apuleia leiocarpa, the equations resulting from models 2, 3 and 5 were excluded since for Dipteryx odorata the equations adjusted by model 2, the regression coefficients $\beta 0$ and $\beta 1$ had VIF equal to 54.76 in addition to presenting $\beta 2$ not significant. In the case of model 3 , its exclusion was due to the fact that the regression coefficient $\beta 0$ is not significant, whereas in the equation generated by model $5, \beta 0$ and $\beta 1$ were not significant, with $\beta 1$ also presenting higher VIF than adopted in the methodology, as well as $\beta 2$ with VIF equal to 63.96 . 
In the case of Apuleia leiocarpa, model 2 was excluded for the same reason as the previous species, differentiating only the value of the VIF, which was 72.58. Model 3 showed $\beta 0$ not significant, whereas in the equation generated by model $5, \beta 0$ and $\beta 1$ were not significant, with $\beta 1$ also presenting higher VIF than the methodology, as well as $\beta 2$ with equal VIF 74.67.

However, unlike the species previous to Amburana acreana, the models resulting from the application of VIF and the significance of the regression coefficients were 1, 3 and 4, emphasizing that the exclusion of model 2 was due to the values of $\beta 0$ and $\beta 1$ being not significant, in addition to $\beta 1$ and $\beta 2$ having a VIF equal to 71.24, and the same goes for the equation adjusted by model 5 with respect to the significance of the coefficients $\beta 0$ and $\beta 1$, emphasizing that the VIF for $\beta 1$ and $\beta 2$ was equal to 76.50. After filtering, the criteria for selecting the best model for the resulting equations were applied (Table 4).

Table 4 Adjusted equations and accuracy statistics with ranking by species.

Tabela 4. Equações ajustadas resultantes e estatísticas de acurácia com ranking por espécie.

\begin{tabular}{|c|c|c|c|c|c|c|c|}
\hline Species & Equation & $\begin{array}{c}\mathbf{R}^{2} \mathbf{a d j} \\
(\%)\end{array}$ & $\begin{array}{l}\text { Syx } \\
\left(\mathbf{m}^{3}\right)\end{array}$ & CV\% & $\mathbf{F}$ & Model & Ranking \\
\hline Dipteryx & $\mathrm{LnV}=-7,36045+2,12128 x \mathrm{LnDt}$ & 87,7 & $\pm 1,26^{*}$ & $14,99 *$ & 609,02 & 1 & $1^{\circ}$ \\
\hline odorata & $\mathrm{V}=-9,2702+0,20864 \mathrm{xDt}$ & 86,0 & $\pm 1,62$ & 19,31 & 516,91 & 4 & $2^{\circ}$ \\
\hline \multirow{2}{*}{$\begin{array}{l}\text { Apuleia } \\
\text { leiocarpa }\end{array}$} & $\mathrm{LnV}=-6,43566+1,90599 \times \mathrm{LnDt}$ & 81,8 & $\pm 1,16^{*}$ & $16,47 *$ & 358,57 & 1 & $1^{\mathrm{o}}$ \\
\hline & $V=-5,96631+0,20864 x D t$ & 81,2 & $\pm 1,30$ & 18,57 & 350,41 & 4 & $2^{\circ}$ \\
\hline \multirow{3}{*}{$\begin{array}{l}\text { Amburana } \\
\text { acreana }\end{array}$} & $\mathrm{V}=1,25518+0,00070003 \mathrm{xDt}^{2}$ & 70,5 & $\pm 0,97$ & 17,87 & 197,29 & 4 & $1^{\circ}$ \\
\hline & $\mathrm{LnV}=-4,54407+1,43334 x \mathrm{LnDt}$ & 64,1 & $\pm 0,93 *$ & $17,13 *$ & 147,03 & 1 & $2^{o}$ \\
\hline & $\mathrm{V}=-2,96777+0,11041 \mathrm{xDt}$ & 68,4 & $\pm 1,01$ & 18,51 & 178,29 & 3 & $3^{\circ}$ \\
\hline
\end{tabular}

Where: $\mathrm{LnV}=$ Natural volume logarithm; V = volume $\left(\mathrm{m}^{3}\right) ; \mathrm{LnDt}=$ Natural logarithm of the stump diameter; Dt $=$ Stump diameter $(\mathrm{cm}) ; *$ correction by FI.

According to Table 4, model 1 was the one that best fit the data of commercial volume and stump diameter for the species Dipteryx odorata and Apuleia leiocarpa, and model 4 (Hohenald \& Krenn model) was the best fit for Amburana acreana, both of which are simple input equations.

The following is the graph of dispersion of residues of the species studied (Figure 3 ).

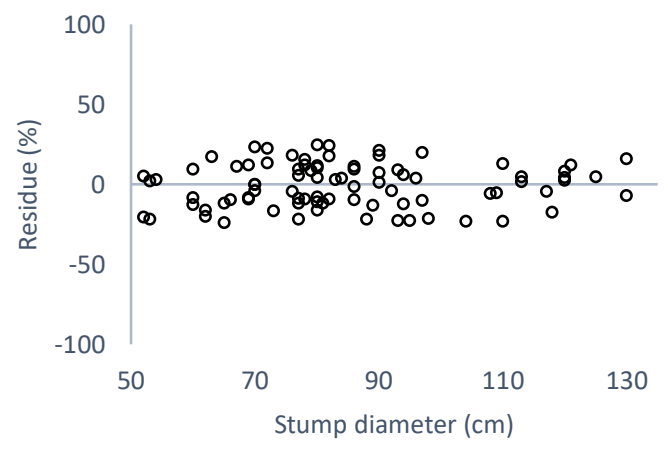

(a) Dipteryx odorata

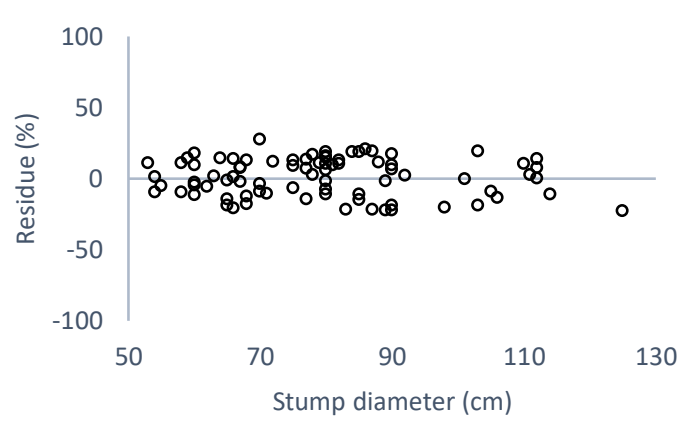

(b) Apuleia leiocarpa

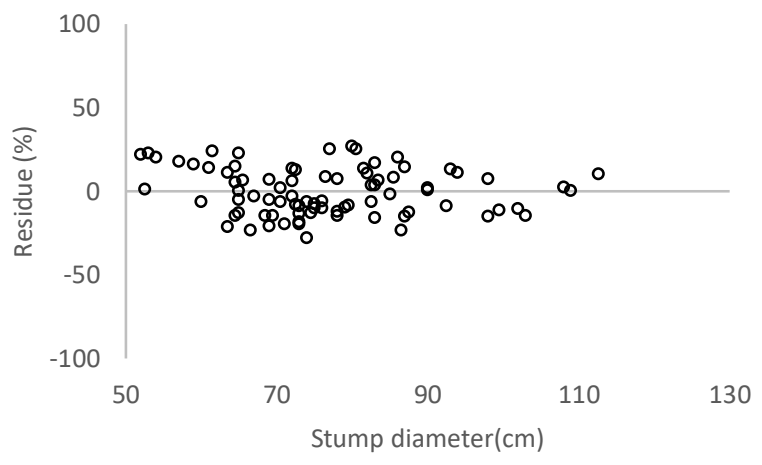

(c) Amburana acreana

Figure 3. Residual distribution by species. 
Figura 3. Gráfico de distribuição dos resíduos por espécie

The Chi-square probability test revealed adequacy of the estimates for the test sample for all species (Dipteryx odorata with a value of 0.9982, Apuleia leiocarpa with a value of 0.9999 and Amburana acreana with a value of 0.9987$)$.

The model identity test showed that the Dipteryx odorata and Apuleia leiocarpa species commercial volume can be estimated by a single regression equation according to covariance in the common intercept (species, $\operatorname{Pr}>0.05$ ) and in the interaction (species $\times \mathrm{LnDt}, \mathrm{Pr}>0.05$ ) as assessed in the lines of Figure 4 .

In the case of Amburana acreana, there was a common intercept. However, for trees with a stump diameter greater than or equal to $66.00 \mathrm{~cm}$, there is a change in the slope as the probability test presented $(\operatorname{Pr}<$ $0.05)$.

Therefore, the equation resulting from the Husch model was $\mathrm{LnV}=-6.63018+1.9114 \times \mathrm{LnDt}$, with $\mathrm{R}^{2} \operatorname{adj}(\%)=85.36$, Syx $= \pm 1.13, \mathrm{CV}(\%)=16.22$ and $\mathrm{F}=963.01$, for identity between models.

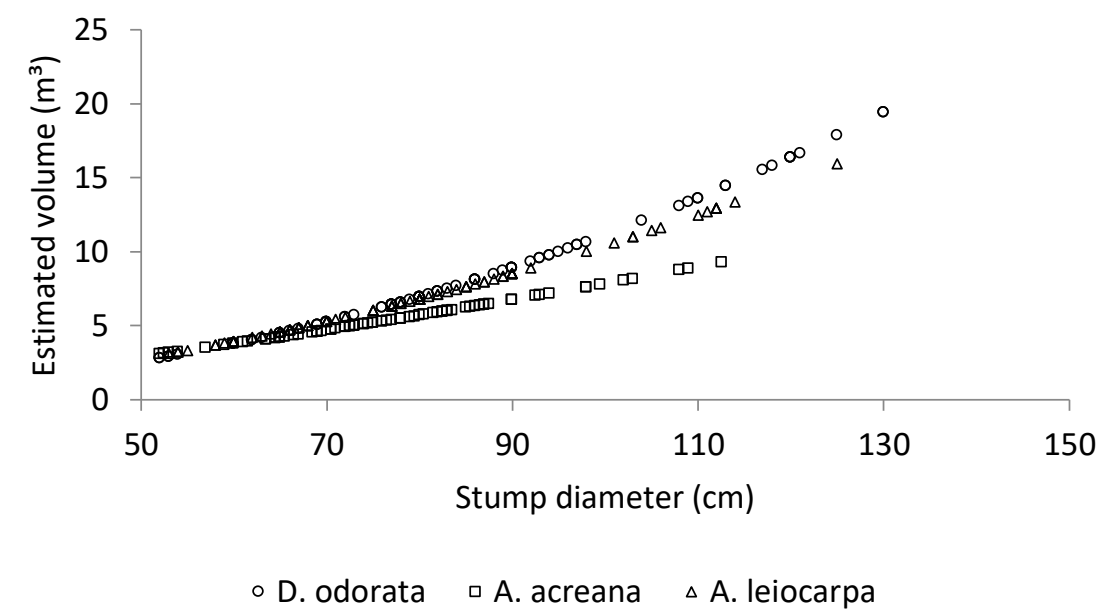

Figure 4. Volume estimated by equation adjusted for the three species by the Husch model.

Figura 4. Volume estimado por equação ajustada para as três espécies pelo modelo de Husch.

\section{DISCUSSION}

The use of variables with a strong correlation indicates the possibility of good equation adjustments. When the results of the analysis for the correlation between the studied variables were observed, a strong positive correlation was observed between them, with a value equal to or greater than $90 \%$ for the species Apuleia leiocarpa and Dipteryx odorata, these results being similar to those presented by Cunha et al. (2016). For Amburana acreana, the value was lower than that found for other species. However, as observed by Bett; May (2017), is a good result.

The best fit was obtained by the Husch model, for the species Dipteryx odorata and Apuleia leiocarpa, in the present study. Leite and Resende (2010) carried out a study for a population with several species, obtaining better results for the Berkhout model to estimate the volume from the diameter of the stump.

In the case of Amburana acreana, the model that provided the best fit was the Kopezky-Gehrhardt model (Table 4), with a lower coefficient of determination than that obtained for the other species studied. Despite this, Leite et al. (2003) consider that values above $60 \%$ for the determination coefficient present values of goodness of fit for species in Amazon.

Miranda et al. (2013) and Gimenez et al. (2015) carried out studies using double entry equations with $\mathrm{DBH}$ and $\mathrm{CH}$ (commercial height) variables for the population and, excluding the coefficient of determination, obtained statistics similar to those obtained by the present study.

Regarding the tests of the regression assumptions, just as in the study by Cunha et al. (2016), the equations adjusted by the models selected for the three species met the same, presenting homogeneity, independence and normality of the residues.

The behavior of the percentage residues for the equations selected for the species Dipteryx odorata, Apuleia leiocarpa and Amburana acreana in the present study revealed the absence of a trend along the distribution, as in the studies by Amaro et al. (2013); Milk; Resende (2010).

With the application of the Chi-square test, in which the values of the calculated volume and volume estimated by the regression were compared, it was observed that there was no statistical difference between them, 
just as other authors used the test to validate the data, which can be mentioned among them Leal et al. (2015); Barros; Silva Júnior (2011).

The model identity study assumes the use of a single model. Although Husch's model was not the best for Amburana acreana, it was used in the model identity for the three species. With the stump diameters approaching the $60 \mathrm{~cm}$ class, the model for Amburana acreana follows an angular distribution trend different from Dpteryx odorata and Apuleia leiocarpa, thus demonstrating that there is a variation that does not allow the use of a single equation for the three species.

\section{CONCLUSIONS}

- It was possible to estimate the volume using statistical equations precisely using the diameter of the stump.

- Volume equations for the species Dipteryx odorata, Amburana acreana and Apuleia leiocarpa were adjusted, with the Husch model showing the best fit resulting in the equations $\mathrm{LnV}=-7.36045+2.12128 \times \mathrm{LnDt}$ and $\mathrm{LnV}=-6.43566+1.90599 \times \mathrm{LnDt}$, respectively, and for Amburana acreana the best model was KopezkyGehrhardt resulting in the equation $\mathrm{V}=1.255518+0.00070003 \times \mathrm{Dt}^{2}$.

- All the selected equations met the tests of regression assumptions (normality, independence and homogeneity) for the residuals.

- The Chi-square test demonstrated the validity of the equations, since there were no statistical differences when comparing the estimate result with the volume obtained through the rigorous cubing of the sampled individuals.

- It was not possible to obtain a single equation for the studied species, since with Dt equal to or greater than $66.60 \mathrm{~cm}$, the regression slopes show different behavior.

\section{ACKNOWLEDMENTS}

To the Acre Environmental Institute (IMAC), for the opportunity to carry out this work, and to the forest engineer Rogério Magalhães Ferreira, for his help in collecting samples in the field.

\section{REFERENCES}

AMIN, A.; CHOUMERT-NKOLO, J.; COMBES, J.-L.; COMBES MOTEL, P.; KÉRÉ, E.N.; ONGONOOLINGA, J.-G.; SCHWARTZ, S. Neighborhood effects in the Brazilian Amazônia: Protected areas and deforestation. Journal of Environmental Economics and Management. Amsterdam, v. 93, p. 272 - 288 , jan. 2019.

ALMEIDA, A. N.; ANGELO, H.; SILVA, J. C. G. L.; SOARES, P. R. C.; KANIESKI, M. R. Efetividade do aumento da área de reserva legal por meio de instrumento legal na taxa de desmatamento da Amazônia brasileira. FLORAM, Seropédica. v. 20, p. 143 - 148, abr./jun. 2013.

AMARO, M. A.; SOARES, C. P. B.; SOUZA, A. M., LEITE, H. G.; SILVA, G. F. Estoque volumétrico, de biomassa e de carbono em uma floresta estacional semidecidual em Viçosa, Minas Gerais. Revista Árvore, Viçosa. v. 37, p 849 - 857, set. /out. 2013.

AZEVEDO, G. T. O. S.; AZEVEDO, G. B.; BARRETO-GARCIA, P. A. B.; CONCEIÇÃO JÚNIOR, V. Relações hipsométricas para Eucalyptus urophylla conduzidos sob regime de alto fuste e talhadia no Sudoeste da Bahia. Scientia Plena, Sergipe. v. 9, n. 4, p. 1 - 7, abr. 2013.

BARROS, H. S.; FEARNSIDE, P. M. Soil carbono stok changes due to edge effects in central Amazon florest fragments. Forest Ecology and Management Amsterdam, v. 379, p. 30 - 36, nov. 2016.

BARROS, P. L. C.; SILVA JÚNIOR, A. T. Equação de volume para árvores de uma Floresta Tropical Densa no municipio de Anapú, Oeste do Estado do Pará, Amazônia Ocidental. Revista Ciência Agrária. Belém. v. 51, p. 115 - 126, jan. /jun. 2011.

BETT, L. A.; MAY, D. Regeneração natural de Ocotea odorifera(VELL.) Rohwer (Lauraceae) em Floresta Ombrófila Mista, Paraná, Brasil. Ciencia Florestal, Santa Maria v. 27, n. 1, p. 707 - 717, abr. /jun. 2017.

CUNHA, T. A.; FINGER, C. A. G.; HASENAUER, H. Tree basal area increment models for Cedrela, Amburana, Copaifera and Swietenia growing in the Amazon rain forests. Forest Ecology and Management. Amsterdam, v. 365 , p. $174-183$, abr. 2016. 
CYSNEIROS, V. C.; PELISSARI, A. L.; MACHADO, S. A.; FILHO, A. F.; SOUZA, L. Modelos genéricos e específicos para estimativa do volume comercial e uma floresta sob concessão na Amazônia. Scientia Forestalis, Piracicaba, v. 45, n. 114, p. 295 - 304, jun. 2017.

DUARTE, A. F. Aspectos da climatologia do Acre, Brasil, com base no intervalo 1971 - 2000. Revista Brasileira de Meteorologia, São José dos Campos, v. 21, n. 3b, p. 308 - 317, dez. 2006.

FIGUEIREDO, E. O.; d'OLIVEIRA, M. V. N.; FEARNSIDE, P. M.; PAPA, D. A. Modelos para estimativa de volume de árvores individuais pela morfometria da copa obtida com lidar. CERNE, Lavras, v. 20, n. 4, p. 621 628, abr. 2014.

GIMENEZ, B. O.; DANIELLI, F. E.; OLIVEIRA, C. K. A.; SANTOS, J.; HIGUCHI, N. Equações volumétricas para espécies comerciais madeireiras do sul do estado de Roraima. Scientia Forestalis, Piracicaba, v. 43, n. 106, p. $291-301$, jun. 2015.

GODAR, J.; TIZADO, E.J.; POKORNI, B. Who is responsible for deforestation in the Amazon? A spatially explicit analisis a long the trasamazon higtway in Brazil. Forest Ecology and Manejament. Amsterdam, v. 267, p. 58-73, abr. 2012.

LEAL, F. A.; CABACINHA, C. D.; CASTRO, R. V. O.; MATRICARDI, E. A. T. Amostragem de árvores de Eucalyptus na cubagem rigorosa para estimativa de modelos volumétrico. Brasil Bioma, São Paulo, v. 33, n. 1, p. $91-103$, mar. 2015.

LEITE, F. S.; RESENDE, A. V. Estimativa do volume de madeira a partir do diâmetro da cepa em uma área explorada de floresta Amazônica de Terra Firme. Ciência Florestal, Santa Maria, v. 20, n. 1, p. 69 -79, jan. /mar. 2010.

LEITE, H. G.; ANDRADE, V. C. L. Importância das variáveis altura dominante e altura total em equações hipsométricas e volumétricas. Revista Árvore, Viçosa, v. 27, n. 3, p. 301 - 310. mai. 2003.

LEMOS, A. L. F.; SILVA, J. A. Desmatamento na Amazônia Legal: Evolução, causas, Monitoramento e possibilidades de mitigação através do Fundo Amazônia. FLORAM, Seropédica, v. 18, n. 1, p. 98 - 108 jan. /mar. 2011.

MIRANDA, D. L. C.; AZEVEDO, F. F.; SANTOS, J. P. Determinação do volume de toras da espécie Mezilaurus itauba (Meissn.) Taub. Scientia Plena, Sergipe. v. 9, p. 1 - 7. ago. 2013.

POND, N. C.; FROESE, R. E. Evaluating published approaches for modelling diameter at breast height from stump dimensions. Forestry. London, v. 14, n. 87, p. 683 - 696, dez 2014.

RIBEIRO, R. B. S.; GAMA, J. R. V.; MELO, L. O. Seccionamento para cubagem e escolha de equações de volume para Floresta Nacional do Tapajós. Revista CERNE, Lavras, v. 24, n. 4, p. 605 - 612, out. /dez. 2014.

SCHRODER, T.; PEREIRA, L. D.; HOFIÇÓ, N. S. A. Comparação de métodos de estimativa de volume total para Eucalyptus grandis W. Hill ex Maiden. FLORAM, Seropédica, 2013. Disponível em: <http://www.scielo.br/pdf/floram/2013nahead/aop_floram_033313.pdf>. Acesso em: 05 out. 2017.

SILVA, K. E.; SOUZA, C. R.; AZEVEDO, C. P.; ROSSI, L. M. B. Dinâmica florestal, estoque de carbono e fitossociologia de uma floresta densa de terra-firme na Amazônia Central. Scientia Forestalis, Piracicaba, v. 4, n. 105, p. 193 - 201, mar. 2015.

VANCLAY, J. K., SKOVSGAARD, J.P. Evaluating forest growth model. Ecological Modelling. Amsterdam, v. 98, n. 1, p. 1 - 12, mai. 1997.

VIANA, H. FERNANDES, P.; ARANHA, J. Equações para Estimar a Biomassa Aérea das Principais Lenhosas Arbustivas no Norte e Centro do País. Silva Lusitana, Lisboa, v. especial, p. 99 - 109. jun. 2013.

WESTFAL, J. A. New models for predicting diameter at breats heigth fron stump dimensions. Northern Journal of Forest Research. Washington, D.C., v. 37, p. 21 - 27. mar. 2010. 